\title{
Redistribuição ou reconhecimento 15 anos depois. Um balanço do debate entre Nancy Fraser e Axel Honneth e de sua repercussão no Brasil'
}

Luiz Gustavo da Cunha de Souza ${ }^{2}$

\section{Resumo}

O objetivo deste artigo é discutir como os projetos intelectuais de Fraser e Honneth seguiram vias diversas após o debate que ambos publicaram em 2003 e como estas vias podem ser apropriadas pela teoria social feita no Brasil. Se no momento da discussão, tanto Fraser quanto Honneth procuraram demonstrar a maior adequação de suas respectivas teorias para a análise das lutas sociais e a possibilidade de uma apropriação deu seus modelos pelos movimentos sociais, de modo que o caráter político do debate fosse expresso na forma como movimentos sociais, remeteriam aos termos redistribuição e/ou reconhecimento (I); e, ao longo dos últimos, ambos mudaram o foco de suas análises para um entendimento do próprio sistema capitalista, chegando a concepções alteradas da dinâmica de conflitos sociais (II). Na medida em que este potencial analítico mediou sua recepção no Brasil, isso implica, afinal, novas formas de apropriação e diálogo com as ideias de Fraser e Honneth (III).

Palavras-chave: Redistribuição. Reconhecimento. Conflitos Sociais. Capitalismo. Recepção no Brasil.

I Agradeço à ou ao parecerista anônimo pelos apontamentos críticos e correções. Além disso, trechos desse artigo foram apresentados no $18^{\circ}$ Congresso Brasileiro de Sociologia e no XIV Encontro da BRASA, de modo que agradeço aos comentários e sugestões feitos por colegas nessas ocasiões. Por fim, mas talvez mais importante, muitas das ideias da seção final do artigo puderam ser discutidas com as e os colegas do Grupo de Estudos de Teoria Crítica da UFSC, a quem também agradeço, e particularmente com Franciele Petry, a quem agradeço especialmente.

2 Professor de Sociologia e Teoria Sociológica no Departameto de Sociologia e Ciência Política na UFSC. Contato: gustavo.cunha.s@ufsc.br atribua a autoria da obra, forneça um link para a licença, e indicar se foram feitas alterações. 


\section{Introdução}

Passados 15 anos do debate entre Nancy Fraser e Axel Honneth, um balanço de seus efeitos sobre o desdobramento da obra de cada um deles parece, à primeira vista, resultar negativo. Isso porque, a despeito de terem modificado seus modelos de teoria após o debate, essas mudanças não foram na direção de uma aproximação à posição oposta, e sim em direção à correção de outras fraquezas apontadas em seus respectivos modelos ${ }^{3}$. Tanto uma quanto o outro náo incorporaram de modo substancial as críticas recebidas e, de modo mais geral, desenvolveram seus respectivos modelos em direções que devem pouco àquilo que discutiram em conjunto (FRASER; HONNETH, 2003). Assim, Fraser não parece ter se importado em responder à crítica de que seu modelo de teoria não conecta propriamente a crítica transcendente a um momento de investigação imanente das normas sociais (HONNETH, 2003b, p. 244), mas sim em apresentar o capitalismo como uma ordem social institucional (FRASER; JAEGGI, 2018 , p. 2). Do mesmo modo, Honneth náo parece ter se abalado com a acusação de que sua teoria possuiria pouco apelo crítico (FRASER, 2003b, p. 211) e preferiu continuar com a formulação de uma teoria da justiça baseada na reconstruçáo dos valores e ideais socialmente institucionalizados na interação (HONNETH, 2011, p. 17).

No entanto, quando se observa o debate a partir de seus aspectos menos dialógicos, ao menos três dimensôes parecem lhe ser constitutivas. Em primeiro lugar, a mencionada avaliação dos respectivos modelos de Fraser e Honneth (2003, p. 4) serve ao propósito de cada um deles de construir uma teoria normativa do capitalismo na qual filosofia moral, teoria social e análise política se conectem. Em segundo lugar, e como uma consequência do primeiro ponto, ambos aspiram a que seus modelos teóricos não apenas ofereçam uma melhor caracterização do capitalismo, mas também se prestem a uma melhor tradução ou apropriação por parte das lutas sociais (FRASER, 2003a, p. 11; HONNETH, 2003a, p. 113). Em terceiro lugar, ambos pretendem desenvolver seus respectivos modelos como herdeiros da tradição de pensamento da Teoria Crítica da sociedade - ainda que

3 Um bom exemplo destas mudanças é a discussão realizada por Honneth a respeito da esfera do amor. Ver a este respeito o texto de Patricia Mattos (2018), neste dossiê. 
seus respectivos entendimentos acerca dessa tradição sejam ligeiramente diferentes (FRASER, 2003b, p. 199; HONNETH, 2003a, p. 111). $\mathrm{O}$ que se pretende argumentar aqui é que, a despeito da pouca influência que recíproca exercida, os desdobramentos dos modelos de Fraser e Honneth se dirigem, cada um à sua maneira, à tentativa de caracterizar mais profundamente o capitalismo contemporâneo. Nesse sentido, as críticas recebidas por uma e por outro parecem, ao menos, ter despertado a intençáo de complementar aquela intenção original de apresentar uma teoria normativa do capitalismo a partir das lutas sociais com a adição de uma dimensão sistêmica à caracterização deste modo de produção. Assim fica claro, também, que a referência central de ambos os autores à Teoria Crítica da sociedade é menos interessada em resguardar semelhanças analíticas com esta tradiçáo de pensamento do que em realizar um empreendimento, em linhas gerais, crítico da sociedade presente. Por isso, então, este artigo irá focar majoritariamente nos dois primeiros pontos do debate, isto é, na construção de uma teoria normativa do capitalismo contemporâneo e nos modelos de crítica interna construídos por Fraser e por Honneth.

Isso não significa que tratar da Teoria Crítica seja desimportante, mas que uma discussão adequada sobre sua reconstrução por Fraser e Honneth demandaria uma análise desta corrente de pensamento que ultrapassa a pretensão deste artigo. Além disso, a reivindicação de uma herança da Teoria Crítica parece tão somente um pano de fundo ao qual Fraser e Honneth remetem de modo abstrato e descontínuo. A este respeito, cabe notar, ambos dão muito menos atenção à herança da e ao diálogo com a Teoria Crítica da sociedade do que as leituras exegéticas tendem a considerar importante (FREYENHAGEN, 2017). A exegese - ou reatualização - a partir dos elementos legados pelo modelo de uma Teoria Crítica da sociedade exposto por Max Horkheimer nos anos 1930 parece, de fato, desempenhar um papel puramente nominal nos esforços de Fraser e Honneth, já que a primeira adota uma definição ampla de Teoria Crítica como "o autoesclarecimento acerca das lutas e desejos de uma época” (FRASER, 1985, p. 97), enquanto o alemão aborda essa tradiçáo a partir da herança do hegelianismo de esquerda. O que ambos compartilham, de fato, é a ideia de que o projeto de reatualização da Teoria Crítica se desdobra em três outros eixos que se ligam àquelas duas dimensóes mencionadas anteriormente, a 
saber, a construção de uma teoria do capitalismo e a apropriação por lutas políticas. Estes eixos são: (I) o ponto de apoio empírico da teoria; (II) a conceitualização do capitalismo; e (III) os critérios normativos de crítica e de justificação da crítica (FRASER, 2003b, p. 200-201; HONNETH, 2003 b, p. 238). Novamente, então, fica evidente que a questão central do debate entre Fraser e Honneth é estabelecer uma relação entre a conceitualização do capitalismo presente e a fundamentação de uma crítica ao mesmo tempo normativa e politicamente apropriável a este sistema.

Ora, foi justamente essa conexão com as práticas sociais de crítica, ou os movimentos sociais, que mediou a apropriação, a interpretação e o diálogo que vários autores brasileiros estabeleceram com Fraser e Honneth ao longo da última década e meia (MELO, 2010; NEVES, 2005, 2007; PAIVA, 2015; ROSENFIELD; MELLO; CORRÊA, 2015, SILVA 2008, 2014; SOBOTTKA, 2015; SOUZA, 2003). Ocorre que, como já mencionado, nos últimos 15 anos ambos caminharam em sentidos praticamente opostos no que diz respeito à caracterização normativa do capitalismo e, consequentemente, disso resultaram duas formas muito diferentes de se lidar com as lutas sociais. Exemplos disso podem ser encontrados, por um lado, na recente volta de Fraser à economia e à sociologia políticas (FRASER, 2017; FRASER; JAEGGI, 2018, p. 2), na qual ela busca compreender como se portam os discursos de caracterização e crítica à configuração contemporânea do sistema capitalista; por outro lado, também se encontram exemplos da crescente diferença no tratamento às lutas sociais na tentativa de Honneth de entender o núcleo normativo do projeto socialista como uma proposta de experimentação social a respeito da liberdade (HONNETH, 2015a). Justamente por conta deste maior distanciamento recíproco, a caraterização do capitalismo presente na obra recente de cada um deles acaba por colocar à questão a respeito da possibilidade de reapropriar os desdobramentos do debate sobre redistribuição e reconhecimento um nível adicional: além da tradução política dos conceitos de redistribuição e reconhecimento enquanto gramáticas de conflitos sociais, também no que diz respeito à caracterização normativa do capitalismo é possível colocar a questão de como pensar em uma eventual incorporação frutífera deste debate à teoria social e em especial, em vista da fértil apropriação já ocorrida com o debate, desta incorporação no Brasil. Este último ponto é tanto mais interessante, porque permite desdobrar 
aquela recepção inicial do debate, realizada do ponto de vista de sua relevância para a compreensão dos conflitos sociais brasileiros, na seguinte reflexão: é possível identificar nas caracterizaçóes do sistema capitalista desenhadas por Fraser e Honneth indícios de uma teoria normativa que sirva à explicação da sociedade brasileira?

A fim de lidar com todo este complexo de problemas, o artigo está dividido em três partes: na primeira, é rapidamente exposto como cada um dos autores vai alterando sua caracterização do sistema capitalista ao longo da última década em meia (I); a seguir, são explicadas quais são as consequências dessas alteraçóes para suas respectivas formas opostas de pensar as lutas sociais (II); por fim, com referência ao trabalho mais recente de Honneth (2018a), procuro apontar para algumas implicações dos caminhos deste debate para a teoria social feita no Brasil, aproximando-o, a despeito da possível fragilidade deste passo, de algumas interpretaçóes sobre a formação de sociedade brasileira (III).

\section{O debate entre redistribuição e reconhecimento e as mudanças nos modelos de Fraser e Honneth}

O ponto de partida do debate sobre redistribuição e reconhecimento pode ser retraçado até a crítica feita por Fraser aos modelos de teoria do reconhecimento de Charles Taylor e Honneth. Esta crítica se apoia em dois aspectos fundamentais.

Em primeiro lugar, de acordo com Fraser, a distinção analítica entre redistribuição e reconhecimento parte da contestação de que existem injustiças econômicas, que demandam redistribuição material e promovem uma equalização entre diversos grupos e atores sociais, e injustiças culturais, que demandam reconhecimento e promovem uma diferenciação entre grupos e atores sociais. Todavia, existem também pessoas que são submetidas a ambos os tipos de injustiça, de modo que estes precisam ao mesmo tempo defender e negar suas particularidades, conformando um dilema entre redistribuição e reconhecimento como remédios para as injustiças (FRASER, 2008a, p. 18). O problema, de acordo com Fraser, é que esta emergência de um paradigma de justiça assentado sobre a ideia de reconhecimento se dá não em conjunto com o paradigma da 
redistribuição, mas deslocando-o. Pior: além do deslocamento de problemas de redistribuição, o paradigma do reconhecimento vem acompanhado de um reforço de identidades culturais que acaba por reificá-las por meio de sua simplificação e acomodação em contextos multiculturais (FRASER, 2000 , p. 108). Dado, então, este contexto no qual as lutas por reconhecimento parecem concorrer mais do que convergem com as históricas lutas pela igualdade material, o primeiro aspecto da crítica de Fraser às teorias e políticas do reconhecimento pode ser entendido como uma suspeita náo apenas quanto a este paradigma analítico não ser complexo o bastante para remediar os problemas com os quais lida, mas principalmente de que as práticas políticas associadas ao reconhecimento podem também reverter em dois novos tipos de injustiça, a invisibilização de desigualdades materiais e o sectarismo identitário. Desta suspeita, porém, se desdobra um segundo aspecto crítico quanto ao reconhecimento, que diz respeito à capacidade deste conceito dar conta das lutas sociais devido a seu ponto de apoio.

Em segundo lugar, então, há na crítica de Fraser um aspecto que procura retomar aquelas suspeitas prático-políticas e expandi-las também para o nível conceitual. Este movimento, por meio do qual ela procura associar as teorias do reconhecimento identitário a um paradigma de justiça filiado à tradição do pensamento político que remonta a Hegel e à valorização da ética, do bom, em oposição à tradição de pensamento político que remonta a Kant e à valorização da moralidade, do justo, à qual se filiaria o paradigma da justiça distributiva (FRASER, 2001, p. 23). Ao apontar para esta divisão conceitual, Fraser pretende indicar, na verdade, um problema específico do conceito de reconhecimento: na medida em que este trata o objeto da justiça social como uma concepção de bem que se justifica em práticas discursivas dos indivíduos concernidos, os critérios de crítica desposados por este paradigma precisam também se relacionar a uma dimensão subjetiva da experiência coletiva. De acordo com Fraser, em teorias do reconhecimento como a de Taylor e a de Honneth, as experiências da justiça e do desrespeito são enfrentadas através do questionamento sobre a medida em que afetam as chances de os indivíduos realizarem suas respectivas visóes de uma boa vida, ou colocado em termos mais diretos, suas chances de florescimento mediante uma relação prática consigo mesmos (FRASER, 2001, p. 26). Para a autora, há duas grandes vantagens 
em abandonar este modelo conceitual de reconhecimento e a consequente noção de injustiça como impedimento do florescimento da personalidade. A primeira delas é positiva: seria possível tratar o reconhecimento como uma questão de status igualitário atribuído a diferentes grupos - e não como um desejo subjetivo -, o que garantiria que, em condições de pluralismo sociais como aquelas das sociedades modernas, ao invés do eventual sectarismo decorrente de identidades encasteladas em si, a questáo do reconhecimento fosse tratada a partir do princípio de paridade de participaçáo, de acordo com o qual arranjos institucionais pressuporiam a aceitação de uma norma prévia de paridade quanto à possibilidade de perseguir a própria liberdade, sem contudo demandar a associação daquelas e daqueles que não se reconhecem nos termos propostos que se submetam a esta visão (FRASER, 2001, p. 27). Já a segunda vantagem observada por Fraser no abandono do paradigma do reconhecimento baseado na ética é negativa: ao situar a experiência de injustiça nas relaçóes sociais, seria possível construir uma teoria da justiça centrada no conceito de reconhecimento sem que isso implicasse uma psicologização do sentimento de desrespeito e, logo, do ponto de partida para uma crítica social (FRASER, 2001, p. 28). Assim, o segundo aspecto da crítica de Fraser ao paradigma conceitual do reconhecimento expande suas suspeitas para as consequências analíticas do uso deste conceito, já que, por um lado, ele indicaria uma tensão com o princípio do universalismo pluralista que vige nas sociedades ocidentais desde o século XVIII e, por outro lado, ele psicologizaria a dimensão da crítica social.

Como é sabido, para se contrapor às limitaçôes identificadas, Fraser opta por construir seu modelo por meio da articulação entre os paradigmas populares (folk) de justiça relativos à esfera da economia e da cultura, enquanto Honneth insiste que seu modelo não é uma teoria identitária, e sim uma perspectiva que considera que o conceito de reconhecimento identifica um traço normativo transversal às diversas esferas de organização das sociedades modernas, incluindo aí as da cultura, e do direito, mas também a das relaçóes pessoais e, a partir do debate com Fraser, a da economia. Uma vez que o objetivo aqui não é reapresentar o debate entre eles, mas seguir seus desdobramentos, neste ponto bastam alguns breves apontamentos.

Quanto a Fraser, é importante notar que, seguindo os passos de suas críticas iniciais, ela inicia o debate com Honneth propondo que a 
justiça social seria melhor apreendida através daqueles paradigmas populares de justiça do reconhecimento e da redistribuição exatamente porque eles preservariam expressóes discursivas utilizadas pelas envolvidas e pelos envolvidos nos conflitos sociais sem, contudo, separar substancialmente a sociedade em uma esfera econômica e outra da cultura, já que expressariam demandas - ou remédios para injustiças percebidas - tidas como necessárias dentro de uma determinada situação, e não necessariamente uma essência estanque de determinada demanda situada nesta ou naquela esfera (FRASER, 2003a, p. 63). Este procedimento, que ela chama de dualismo perspectivista, permitiria entender práticas sociais como simultaneamente referentes à dimensão do reconhecimento e da redistribuição e, assim, explicaria porque casos como a subvalorização salarial feminina, mesmo sendo uma questáo econômica, clama pela mobilizaçáo do paradigma do reconhecimento ou, ainda, porque padróes institucionalizados de racismo que afetam a entrada de negros no mercado de trabalho - ainda que tenham origem em aspectos culturais - demandam a mobilização de um paradigma de redistribuição. Este paradigma, porém, logo é complementado com uma dimensão adicional de paridade de participaçáo, que significa que o reconhecimento do status de parceiros plenos de interação só pode ser dado a indivíduos e grupos dos quais se respeita a autonomia igualitária e o valor moral, de modo que essa paridade se transforma em uma "interpretaçâo radicalmente democrática" (FRASER, 2003b, p. 229) da autonomia e adiciona uma dimensão política a seu dualismo analítico, na medida em que os impedimentos institucionais à participação igualitária também demandariam um paradigma próprio de justiça, o de participação. Se esta é uma mudança com relação aos trabalhos anteriores ao debate, dificilmente se poderia afirmar que ela se deve menos a indicaçóes que já se encontravam lá do que às críticas de seu interlocutor.

Isso porque, quanto a Honneth, o que importa notar aqui é que sua defesa de uma teoria do reconhecimento não é uma defesa do modelo criticado por Fraser, já que ele não se identifica plenamente com um modelo identitário de reconhecimento (SAAVEDRA; SOBOTTKA, 2009, p. 397). Antes, ele pretende deixar claro que seu uso da categoria analítica do reconhecimento não se deve a uma conjuntura ditada pelas lutas sociais, mas à forma como uma teoria pode acessar e descrever o modo como 
as expectativas dos sujeitos quanto à sua vida coletiva pode ser desrespeitada (HONNETH, 2003a, p. 126-127). Dessa maneira, Honneth pretende recuperar a noção fundante de sua teoria do reconhecimento, que é a ideia de que a formulação de demandas sociais e a participação em conflitos remete não a princípios morais formulados positivamente, mas à percepção de ferimentos de concepçóes intuitivas de justiça (HONNETH, 2000, p. 99) ${ }^{4}$, de modo que o processo formativo ao qual ele se refere, é mais do que uma remissáo às noçóes subjetivas de boa vida. Antes, a formação da personalidade é um processo interativo no qual expectativas recíprocas intersubjetivamente partilhadas permitem, quando cumpridas, que os indivíduos participem ativamente na vida social. Daí que este conceito de reconhecimento e sua contrapartida no conceito de desrespeito servem não a um diagnostico social, mas ao desvelamento de experiências de injustiça experimentadas pelos sujeitos (HONNETH, 2003a, p. 133). Porém, ao contrário do modelo original do livro Luta por reconhecimento, no qual Honneth fala de esferas sociais de formação da personalidade nas quais se podem distinguir padróes de reconhecimento recíproco nas esferas das relaçóes amorosas, do direito e da estima social (2003c, p. 159), aqui ele já aponta mais claramente para a hipótese de que as sociedades modernas seriam melhor entendidas como uma ordem de reconhecimento (2003a, p. 136-137). Esta mudança o que o leva, afinal, a propor que aquela estrutura de conflitos formativos originalmente proposta em Luta por reconhecimento como uma gramática moral dos conflitos sociais, nas sociedades modernas é ainda mais ampla, pois mais do que lutas pelo cumprimento de expectativas normativas localizadas dentro de esferas de ação específicas, estes são conflitos sobre a interpretação da aplicação de normas de reconhecimento específicas a cada uma das diversas esferas nas quais se subdividem essas sociedades, incluindo aí a esfera econômica (HONNETH, 2003a, p. 154). Isso, finalmente, implica em dois desenvolvimentos de seu trabalho que pouco devem à interlocução com Fraser: por um lado, Honneth terá de dar mais atenção às esferas que não faziam parte de seu modelo inicial, como a da economia; por outro, ele terá de mostrar como estas esferas também podem ser melhor caracterizadas com referência ao conceito de reconhecimento recíproco.

4 Este texto está traduzido para o português neste dossiê. 
Em seus respectivos trabalhos posteriores, as linhas mestras traçadas acima foram seguidas e influências de um sobre o outro são notavelmente pequenas, daí aquela afirmação inicial de que o balanço do debate indicaria que ele não foi frutífero para os envolvidos. Contudo, uma vez que se observe que o debate entre Fraser e Honneth propiciou a chance de que ambos refinassem suas teorias, nota-se que este refinamento se faz justamente através de uma mudança do foco da análise de ambos, dos conflitos sociais para a construçáo de uma teoria normativa do capitalismo.

Fraser, nos diversos artigos publicados nos últimos 15 anos, dedicou-se à tentativa de conceitualizar uma crise do capitalismo neoliberal por meio de uma economia política feminista que supere o descrédito das políticas culturalistas. De acordo com ela, o que é necessário é uma estrutura sensível aos problemas de gênero que possa captar o caráter fundamental dessa crise (FRASER, 2013, p. 12). Nesses textos, Fraser procurou demonstrar que, assim como a crise identificada possui diversos níveis, há uma gramática de resposta dentro da qual os conflitos sociais, com destaque para as lutas feministas, operam. Um elemento central desses artigos é a crítica de um modelo de justiça social baseada no estado de bem-estar social limitado por fronteiras nacionais: de acordo com a autora, tanto as políticas públicas quanto as lutas sociais passam por um momento de readequação à estrutura globalizada do capitalismo contemporâneo e, por isso, demandam uma noção transnacional de justiça. O ponto relevante, no entanto, náo é instruir as lutas sociais a respeito de como responder ao processo de globalização, mas notar que o modelo nacionalizado da justiça sempre tomou como dado que as demandas por justiça seriam enquadradas em um modelo metodológico da cidadania nacional (FRASER, 2008b, p. 274), enquanto na nova fase das lutas sociais, a identificação dos problemas também supera as fronteiras nacionais. Desse modo, ocorre uma mudança na gramática das lutas que ressalta a centralidade da noção de representação: ao contrário das outras dimensôes antes ressaltadas, redistribuição e reconhecimento, representação não diz respeito a algo que falte a alguém (embora também possa faltar), mas à própria estrutura da sociedade: quem tem voz, quem tem status etc. (FRASER, 2008b, p. 276). $\mathrm{O}$ que o processo de globalização efetivamente trouxe à tona, de acordo com Fraser, foi o fato de que diversos processos transnacionais típicos do 
modo de acumulação capitalista não eram acompanhados por um reenquadramento da possibilidade representativa de demandar um tratamento justo em questóes econômicas ou culturais, criando uma dinâmica de injustiça por meio do falso enquadramento (misframing) de demandas (FRASER, 2008b, p. 281). Consequentemente, em uma sociedade na qual os parâmetros nacionalizados de regulação da cidadania são ultrapassados, resta à dinâmica da esfera pública na qual se expressam os indivíduos concernidos tentar acompanhar tal movimento. Em termos mais simples, resta à esfera pública na qual se fazem demandas por justiça correr atrás da dinâmica de transnacionalização.

Para isso ocorrer seria necessário, finalmente, que a noção de esfera pública fosse alterada e é isso que Fraser se propóe a realizar conceitualmente por meio de uma crítica à associação tradicional entre cidadania nacional e direitos sociais. Para ela, na nova situação social, a esfera pública de debates políticos deveria se orientar antes por um princípio segundo o qual seus concernidos não seriam os membros de uma comunidade definida de modo binário, mas todos aqueles afetados conjuntamente por uma estrutura governante que defina seus parâmetros de interação (FRASER, 2009, p. 96). Quando se trata de um modo de produção e acumulação globalizado, trata-se também de um público apto a criar demandas por justiça que também é globalizado, de modo que nesta nova fase de sua obra, Fraser irá se dedicar a entender os conflitos sociais a partir daquilo que se poderia chamar de práticas discursivas contra-hegemônicas como modelos de crítica. Mas, antes de passar a isso, na próxima sessão, cabe notar algo mais: que em sua caracterização dos novos desafios colocados frente à teoria da justiça, Fraser adota o vocabulário de um regime de governança global ao se referir ao modo de produção e acumulação capitalista. A partir desse ponto, fica claro que, de acordo com Fraser, para que se entenda a presente dinâmica dos conflitos sociais, será também necessário caracterizar melhor o sistema capitalista como um todo, pois só assim se poderá entender como é que essa dinâmica de conflitos sociais indica também a existência de uma crise.

Todavia, ao contrário de outras posiçóes que recentemente procuraram tratar do capitalismo neoliberal como um discurso (BROWN, 2015)

5 Cf. capítulo 1. 
em seu recente diálogo com Rahel Jaeggi, Fraser adota uma visão do capitalismo como um sistema inerentemente histórico, cujas mudanças seriam caracterizadas, mais do que como variedades, como uma sequência de momentos históricos interligados e cuja trilha de mudanças seria "politicamente conduzida e certamente remontável aos conflitos entre proponentes de diferentes projetos" (FRASER; JAEGGI, 2018, p. 15). Esse modelo de um sistema social institucionalizado implicará uma mudança na forma como se lida com os conflitos sociais, como se mostrará na próxima sessão. Antes disso, porém, falemos de Honneth.

Também Honneth, ao longo dos últimos 15 anos, aprofundou um projeto já esboçado antes do debate com Fraser: reconstruir a filosofia política hegeliana em bases pós-metafísicas (HONNETH, 2000). Esse projeto, se não é uma ruptura com o modelo teórico construído em Luta por reconhecimento, apresenta um ponto de inflexão que será importante para a obra posterior de Honneth - e afetará de modo decisivo o debate acerca de sua recepção o Brasil. Isso porque a já mencionada ambição de ampliar o escopo da teoria do reconhecimento, apresentando-a não mais como uma gramática das lutas sociais, mas sim um fundamento da democracia liberal, requer dois passos aparentemente difíceis de conectar. Por um lado, será preciso que o conceito de reconhecimento deixe de remeter apenas a um momento da formação da personalidade que ocorre em meio a um conflito mediado por expectativas normativas; por outro lado, será preciso demonstrar onde se encontram princípios de reconhecimento que fundamentem esta nova e mais ampla tese. A dificuldade aqui é que, ao mesmo tempo em que o conceito de reconhecimento deixa de ser específico àquelas três esferas do amor, do direito e da estima, passando a ser um fundamento da democracia, ele também precisa ser localizado como princípio implícito das formas institucionais da modernidade liberal (se trata de uma teoria da democracia, afinal). Ou seja, ao mesmo tempo em que passa a ser tudo, reconhecimento precisa ser institucionalmente bem localizado. A princípio, tal movimento coloca Honneth sob a suspeita de assemelhar seu conceito de reconhecimento com uma noção de solidariedade que, no mais, dificilmente seria apta a dar conta das tensóes das sociedades pluralistas e democráticas das quais ele pretende tratar (SIEP, 2011, p. 131). No entanto, parece claro que Honneth está tratando de duas coisas diferentes 
com o mesmo conceito, pois a mudança em sua teoria diz respeito menos à base conceitual e mais à arquitetura e escopo. Assim, parece correto interpretar esta mudança como uma tentativa de interpretar a infraestrutura das sociedades modernas adaptando e readequando o conceito de reconhecimento a este propósito.

Porém, é preciso lembrar que o conceito de reconhecimento, conforme usado por Honneth, não diz respeito à luta social por identidade é dizer: não diz respeito à luta em si - mas à confirmação recíproca de identidades. Uma vez que sua caracterização seja ampliada de um objeto de lutas ${ }^{6}$ para a de um material, um tecido ${ }^{7}$ da sociedade (HONNETH, 2011, p. 124), o uso dado ao conceito de reconhecimento deixa de ser o de um critério normativo das lutas sociais e passa a ser o de um critério normativo das instituiçóes coletivas; e na medida em que agora ele pretende dar conta de outras esferas da vida social, exemplarmente da

6 P. e. Honneth (2003c, p. 257).

7 Conferir a este respeito, o artigo "A textura da justiça" (HONNETH, 2009), no qual, em diálogo com a teoria da justiça de David Miller. Honneth contrapõe seu modelo (hegeliano) de teoria da justiça aos modelos kantianos construtivistas, cujo mais influente é evidentemente o de John Rawls. Não por acaso, este artigo de Honneth dialoga diretamente com a introdução de seu livro $O$ direito da liberdade, onde a ideia-força ganha nova versão: "Teoria da justiça como análise da sociedade". Ao contrário do que afirmei em outro lugar (Souza, 2017). esta não é uma mera mudança de um modelo calcado na sociologia para outro mais influenciado pela filosofia, particularmente pela filosofia da História. Mais justo seria dizer que a referência sociológica de Honneth deixa de ser o conflito, como em Mead e na tradição interacionista, e passa a ser a reprodução social, como em Parsons (sua referência no trecho citado na continuação deste parágrafo). Curiosamente, porém, mais à frente no liuro, Honneth (2011, p. 118) cita Durkheim como o autor mais importante, após Hegel, para sua tese de que existem condições extrajurídicas da justiça, revelando encontrar neste autor, particularmente nas Lições de sociologia - ver Durkheim, 2002, p. 237-304 - a ideia de que a legitimação dos valores dos quais partilham os individuos tem prioridade sobre as instituições reguladoras e orienta sua construção ao longo do tempo. Ainda mais curiosa é uma frase, aqui em minha tradução como todas as citações no artigo, com a qual Honneth inicia seu livro mais recente, sobre as diferentes valorações normativas dadas ao conceito de reconhecimento em diferentes contextos intelectuais nacionais: "[...] apenas no espelho de uma tal confirmação histórica [de conceitos] podemos conjuntamente conhecer, porque nós nos tornamos aquilo que nós somos, e quais demandas normativas acompanham este autoentendimento compartilhado" (HONNETH, 20I8a, p. 13). Se esta introdução remete inevitavelmente ao método da reconstrução normativa, ecoa a importância do compartilhamento de valores naquele sentido durkheimiano, mas também uma ideia de Norbert Elias, que n'O processo civilizador (ELIAS, 1990, 1993) descreve o desenvolvimento de um aparelho interno de autocontrole como um processo de apreensão e posterior reformulação de normas que dão uma conformação psicossocial às sociedades - ou a quem vamos gradualmente nos tornando, para falar com Honneth. Tais aproximações, mais do que meras curiosidades, parecem indicar que o método reconstrutivo adotado por Honneth comporta um diálogo frutifero com uma certa tradição sociológica reconstrutiva. Eis um projeto a ser desenvolvido. 
economia, aquele duplo requerimento de ampliar e determinar o conceito de reconhecimento se expressa no fato de que nesta nova fase Honneth não pode escapar à conceitualização do sistema de produção, tanto quanto não pode escapar à conceitualização do sistema de representação: capitalismo e democracia, por caminhos diversos e em formas diferentes das de Fraser, também se tornam centrais para sua teoria. Contudo, o modelo de reconhecimento como confirmação recíproca que é transportando para a análise da integração sistêmica traz consigo aquela especificidade de apelar a normas partilhadas, de modo que Honneth busca resolver a conjugação entre ampliação e especificação do conceito de reconhecimento através de uma "reconstrução normativa" (HONNETH, 2011, p. 23) dos valores e normas coletivamente partilhados aos quais os indivíduos podem remeter, como se fossem expectativas normativas coletivizadas. E, assim como no uso inicial do conceito de reconhecimento, este se referia a uma relação implicitamente existente, aqui também se parte deste ponto, de modo que a escolha do método reconstrutivo já deve ter feito saltar aos olhos uma implicação que diferencia claramente este modelo de teoria adotado por Honneth. Enquanto Fraser se vale de uma caracterização diagnóstica, referida à globalização e à transnacionalização do regime produtivo, e resultando em momentos históricos que desenvolvem três características fundamentais desse modo de produção, propriedade privada dos meios de produção, existência de mercados livres de compra e venda da força de trabalho e dinâmica de acumulação de capital em oposição ao consumo, isto é apropriação ao invés de satisfação (FRASER; JAEGGI, 2018, p. 1518), Honneth (2011, p. 19 e ss) reconstrói este modelo do ponto de vista de um "funcionalismo normativo", ou seja, a ideia de que a reprodução de qualquer sistema ou subsistema de açáo social depende fundamentalmente da legitimação vinda dos atores envolvidos. Colocado na perspectiva daquela mudança de rumo identificada inicialmente no debate, de acordo com a qual ele pretende interpretar, entre outros, o subsistema econômico como uma rede de relaçóes recíprocas de reconhecimento, isso faz com que também o mercado de compra e venda de trabalho deva ser tomado como um subsistema de ação que se institucionaliza a partir de negociaçóes a respeito de seus valores e normas de orientação, de modo que esta esfera e, com ela, o modo de produção e troca capitalista são agora concebidos a 
partir da tensão entre sua estrutura normativa - basicamente uma rede de satisfação recíproca de necessidades através do reconhecimento implícito - e, do outro lado, patologias ou falsos desenvolvimentos dessas relaçóes. Consequentemente, as lutas por reconhecimento dão lugar a uma maneira de analisar o conflito social que seja condizente com a interpretaçáo de normas de orientação.

Tanto nos estudos principais (HONNETH, 2011, 2015a) quanto em diversos artigos (HONNETH, 2014, 2105b), acompanhou o projeto reconstrutivo de Honneth a modificação da noção de injustiças sociais. Se até o momento do debate com Fraser ele ainda procurava interpretar a gramática moral dos conflitos sociais a partir de um esquema interacionista baseado na psicologia moral de George Herbert Mead, ao longo da última década e meia Honneth gradualmente substitui este modelo por um outro, mais influenciado por John Dewey e Émile Durkheim, resultando em uma teoria na qual a intersubjetividade possui caráter menos interpessoal e mais institucional. Apesar do aparente contrassenso, esta parece ser a condição essencial para aquilo que ele chama de liberdade social. Nesse sentido, reconhecimento passa a fazer parte do pano de fundo normativo da sociedade, assim como a redistribuição, uma vez que a realidade social é que deve ser concebida como uma série de arranjos institucionais nos quais as codeterminaçóes recíprocas dos sujeitos são mediadas por normas e valores tacitamente partilhados (HONNETH, 2011, p. 69-70). Evidentemente, trata-se de um conceito modificado de reconhecimento, muito menos voltado para as lutas sociais do que para os critérios normativos de entendimento recíproco, o que implica também que as tensóes sociais, neste modelo de teoria da sociedade, se dão no nível da relação entre sujeitos e normas partilhadas de orientação coletiva. $\mathrm{Ou}$, como o próprio Honneth (2011, p. 158) coloca, assim como a conciliação ocorre entre sujeitos e a realidade institucional, as injustiças, dentro deste modelo teórico, são concebidas como desordens de segunda ordem, como patologias sociais que se manifestam como compreensóes equivocadas ou incompletas dos pressupostos de reciprocidade que constituem a sociedade. Essa tensão entre a construção normativa de valores partilhados e falsos desenvolvimentos é o que permite a Honneth caracterizar o atomismo e a atrofia dos mercados antes como falsos desenvolvimentos, que contrariam as normas implícitas 
de satisfação recíproca que estão inscritas na realidade institucional de um sistema de mercado, afinal (HONNETH, 2011, p. 360).

Portanto, mais uma vez aqui se depara com um novo distanciamento entre Fraser e Honneth: se ela caracteriza uma ordem social institucional de produção e reprodução do capital, ele caracteriza uma rede de normas partilhadas e reproduzidas pelos sujeitos; se ela fala de um sistema de reprodução social que bloqueie horizontes de valores centrados na cooperação e module a reprodução social pelos interesses sistêmicos (FRASER; JAEGGI, 2018, p. 31), ele caracteriza um sistema de potencial satisfação recíproca de necessidades como uma arena na qual não é na atividade laboral que se deve buscar a normatividade, mas justamente dentro da dimensão sistêmica da divisão do trabalho (HONNETH, 2008, p. 54); se ela critica um sistema, ele critica uma relação. Quem são os sujeitos desta crítica e como ela desenvolve são os temas da próxima sessão.

\section{Teorias do capitalismo e dos conflitos sociais: contra-hegemonia e patologias sociais}

A caracterização dos conflitos sociais é central tanto para Fraser quanto para Honneth porque fundamentalmente expressa o potencial crítico com que ambos os autores pretendem equipar seus respectivos modelos de teoria. Assim, como herdeiros de uma Teoria Crítica, para cada um deles é importante identificar tensôes que funcionem como mediadoras da superação do atual estado de coisas em direção a um horizonte emancipatório. $\mathrm{E}$ aqui as caracterizaçóes diversas oferecidas por ela e por ele revelam um efeito adicional de discordância, desta vez a respeito de como pensar os efeitos das lutas sociais. Este último tópico, aliás, é o que permitirá aludir, na próxima sessão, à utilidade dos modelos recentes de Fraser e Honneth para a sociologia brasileira. Nesta sessão, por outro lado, buscar-se-á apresentar o modelo de lutas contra-hegemônicas proposto por Fraser e o modelo de experimentalismo social defendido por Honneth.

Comecemos por Fraser. Em um texto recente, chamado From progressive neoliberalism to Trum $p^{8}$ no qual procura, em primeiro lugar, caracterizar

8 Traduzido para o português neste dossiê. 
com mais detalhes a crise de que vinha falando ao longo dos últimos anos, mas também demonstrar como esta crise está ligada à ascensão do populismo de direita, ela chega à seguinte constatação: trata-se de uma situação na qual a crise de legitimidade da política nada mais é do que a ponta de uma crise global multifacetada, que inclui dimensóes econômicas, sociais e ecológicas e que se expressa como a crise de um modelo social. Daí que Fraser afirma que a corrente política dessa crise sistêmica é antes uma crise de hegemonia ou, ainda, uma crise no bloco hegemônico responsável por naturalizar e gerenciar as pressuposiçóes de sua própria visão de mundo (FRASER, 2017, p. 47). Entretanto, Fraser não pretende meramente retomar os termos de Antonio Gramsci em sua explicação da crise sistêmica, mas expôr a tese de que o bloco hegemônico em crise se conforma através de uma ligaçáo específica entre dois aspectos particulares dos principais paradigmas populares de justiça, aquele responsável pela estrutura econômica da sociedade e por sua divisão de classes, o paradigma da redistribuição, e aquele responsável pela atribuição de respeito e estima sociais e pelo estabelecimento de hierarquias sociais, o paradigma do reconhecimento. Ao incorporá-los à teoria gramsciana da crise, Fraser pretende demostrar que o bloco hegemônico em crise sofre com o descrédito de seu "distintivo nexo normativo entre redistribuição e reconhecimento" (FRASER, 2017, p. 49), mas do mesmo modo, essa crise de hegemonia aponta para possibilidades de organização de um bloco contra-hegemônico.

Em primeiro lugar, então, Fraser chama atenção para a hegemonia de um bloco que conseguiu unir um programa econômico plutocrata e explorador, cujo epítome são os investidores do capital financeiro, mas que inclui também empresários do entretenimento e das novas comunicações, e uma política liberal e meritocrática no que diz respeito ao reconhecimento, representado pelas correntes do feminismo, antirracismo e multiculturalismo mainstream. Ocorre que, se a face econômica do programa desse bloco foi moldada pelos movimentos de direita, em uma sociedade ainda fortemente marcada pela emergência dos movimentos sociais dos anos 1960 e pela revoluçáo cívica do período de Franklin D. Roosevelt ${ }^{9}$, o

9 Para além das referências acadêmicas dadas por Fraser, um guia através da ascensão e crise do neoliberalismo progressista, desde suas origens nos anos Roosevelt, está nas novelas da trilogia americana de Philip Roth, 
projeto neoliberal regressivo encontraria dificuldades de legitimação. Daí a necessidade de uma convergência, dada pelos liberais a este bloco, com a adição de políticas progressivas de reconhecimento àquele cenário econômico, especialmente aquelas que permitiram que as pautas emancipatórias e progressistas fossem transformadas em válvulas de escape meritocrático para políticas ainda fortemente centradas na reprodução econômica das classes sociais e na mobilidade ascendente do capital mais do que das pessoas. O resultado é o que Fraser chama de "neoliberalismo progressista” (FRASER, 2017, p. 47), um nexo de políticas econômicas regressivas com uma interpretação limitante do núcleo duro das reivindicações sociais daqueles grupos inicialmente associados às políticas de reconhecimento, como mulheres, afrodescendentes e movimentos LGBTQ e ambientalistas (FRASER, 2017, p. 50). O resultado, como está claro, é uma aliança entre o liberalismo de costumes domesticado, pois mediado pela ideologia do mérito mais do que pela ascensão social coletiva, e o neoliberalismo econômico regressivo desregrado.

O paradoxo dessa situação, porém, não é a conformação de um bloco que una progressistas e neoliberais, mas sim que para tanto o bloco hegemônico em questão teve de deslocar o neoliberalismo reacionário e também o liberalismo progressista, ou seja, enquanto o neoliberalismo englobava elementos progressistas em seu bloco hegemônico, os progressistas das classes oprimidas eram excluídos deste bloco, por se manterem críticos ao aspecto econômico regressivo deste projeto político, a despeito da apropriação de algumas de suas demandas. Ao longo da década de 1990, este é o argumento de Fraser, o neoliberalismo progressista, multiculturalista, teria subjugado a versão etnonacionalista do neoliberalismo, mas, ao mesmo tempo, bloqueado o espaço para projetos de reconhecimento associados a formas econômicas contrárias ao neoliberalismo, já que a diferença fundamental entre os projetos neoliberal e progressista diz respeito ao reconhecimento, e não à redistribuição (FRASER, 2017, p. 52). Porém, como explicitado pela vitória de Donald Trump nas eleiçôes estadunidenses de 2016, este bloco hegemônico do neoliberalismo progressista 
também enfrenta um momento de crise, e acaba deslocado por uma versão do neoliberalismo regressivo, em que a agenda economicamente neoliberal se liga a uma versão reacionária das políticas de reconhecimento, marcada por uma retórica nacionalista, misógina e islamofóbica, quando náo contemporizando o neonazismo, resultando em uma versão "neoliberalismo hiper-reacionário” (FRASER, 2017, p. 56). Este último aspecto se torna tanto mais evidente se voltarmos o olhar para a recente emergência de discursos nacionalistas e xenófobos na Europa e nos Estados Unidos ou, mais próximo de nós, no crescente apoio a plataformas militaristas e violentas dentro do discurso público brasileiro.

Ainda que Fraser desde o começo de sua participação no debate do reconhecimento tenha chamado a atenção para os riscos da política da identidade, sua maior preocupação teórica ao criticar o reconhecimento foi com a psicologização do conflito social ou com a reificação de identidades. Os conflitos nos quais o reconhecimento e a autoidentificação identitária são usados como meio de poder, por outro lado, pareciam ocupar um lugar subalterno para ela - e ainda parecem, já que, mesmo em sua crítica ao bloco neoliberal hiper-reacionário, o adversário não são os movimentos etnonacionalistas e conservadores que apoiaram e sustem Trump, governos xenófobos na Europa e no sudeste asiático ou candidatos protofascistas, como Jair Bolsonaro, no Brasil; pelo contrário, o foco de sua análise é a constituição de uma forma sistêmica de dominação que normaliza a confluência de interesses neoliberais e hiper-reacionários.

Entender a mobilização do arsenal do reconhecimento como parte de uma disputa política também pelo encastelamento das próprias posiçôes de poder é, porém, a preocupação investigada e descrita pela socióloga alemã Barbara Kaletta (2008), que se vale da noção de animosidade dirigida a grupos. De acordo com ela, reconhecimento somente pode ser descrito de modo positivo quando a ele se atrela alguma correspondência, isto é, quando o reconhecimento recebido está associado à autodefinição dos sujeitos ou ainda quando a demanda por reconhecimento por parte de outrem não se choca com as próprias expectativas ${ }^{10}$. Existem casos, porém, em que a

10 É evidente que Kaletta (2008) está associando reconhecimento com autoidentificação, mas não no sentido de uma identidade cultural, como Fraser entende. Aqui ela segue Honneth ao entender que autoidentificação é 
distribuição ou a demanda por reconhecimento revelam o lado negativo das relaçóes sociais, por exemplo, quando alguém usa sua capacidade de atribuir reconhecimento como uma forma de poder ou, de modo inverso, quando as demandas por reconhecimento são claramente exageradas ${ }^{\prime \prime}$. O que há de relevante na análise de Kaletta, porém, é que, ao invés de tentar desqualificar a importância que os sujeitos atribuem ao reconhecimento ou às próprias práticas de reconhecimento, ela toma essa prática como uma fonte de integração social cuja ausência pode resultar na construção de atitudes de animosidade: ao relacionar reconhecimento e desintegração social, diz ela, é possível notar que a ausência de correspondência entre as expectativas de reconhecimento e as práticas que uma pessoa vivencia pode levar à ruptura de laços sociais. Uma resposta à falta de integração, por sua vez, pode ser a reconstruçáo positiva da própria imagem, mas esta reconstruçáo por vezes se dá através da desvalorização de outros grupos, frequentemente mais fracos ou em situação mais precária (Kaletta, 2008: 39) ${ }^{12}$. Neste caso, o reconhecimento funciona como uma espécie de encastelamento da própria personalidade, mas em termos sociais - e dentro de sociedades marcadas pelo pluralismo étnico-racial, sexual, de gênero, de moral etc. - este encastelamento se expressa como práticas de distinção simbólica.

Esse aspecto das lutas sociais recebe pouca atenção de Fraser, afinal, pois em sua exposição ela aposta antes na possibilidade de organização de blocos contra-hegemônicos que não retomem o nexo entre progressismo e

uma questão de desenvolvimento da própria personalidade. Por isso, é possivel receber reconhecimento (como uma boa dona de casa, ou como um bom cumpridor de ordens) sem que isso seja positivo, pois não faz parte das expectativas da pessoa e, por isso mesmo, a atribuição de reconhecimento não supre a necessidade moral dos envolvidos.

II Uma boa tipologia das práticas de reconhecimento está no livro de McBride (20/3). Para os casos mencionados aqui, basta pensar, por exemplo, no primeiro caso, em um patrão que abusa das horas extras de seus empregados mas os estima por aceitarem o abuso e, no segundo caso, em um jogador de futebol talentoso que chantageia seu clube ameaçando ir jogar em outro lugar se suas exigências salariais irreais não forem cumpridas.

12 Exemplos de animosidade dirigida a grupos são, para Kaletta: racismo, xenofobia, antissemitismo, homofobia, preconceitos contra moradores de rua, contra portadores de necessidades especiais, islamofobia, sexismo, preconceitos contra outsiders de modo geral e desvalorização de pessoas desempregadas há longo tempo. É óbvio que as categorias de animosidade aqui são marcadas pela realidade social alemã, mas várias delas encontram paralelo no Brasil (racismo, homofobia, sexismo); outras poderiam ser traduzidas a partir de práticas aqui encontradas, como a xenofobia. Além disso, uma terceira leva de categorias como o desprezo social (NEVES, 2007) ou a subcidadania (SOUZA, 2003), por exemplo, poderiam fazer parte deste quadro. 
neoliberalismo, e sim na retomada de um programa de liberalismo progressista quanto ao reconhecimento combinado com um programa econômico populista crítico da redistribuição em termos neoliberais, isto é, em uma combinação de lutas pelos efeitos do reconhecimento multicultural e da economia de redistribuição, apontando para um populismo progressista ou, ainda, um populismo contra-hegemônico (FRASER, 2017, p. 59). Para Fraser, falar de contra-hegemonia é necessário, porque a recente crise do bloco hegemônico expôs o limite da aliança entre formas domesticadas de reconhecimento e regressivas de redistribuição: mesmo incluindo diversos grupos de reivindicação a partir de suas demandas por uma política multicultural liberal, o neoliberalismo progressista é incapaz de moralizar o capitalismo a partir da inserção de interesses dos grupos subalternos (mulheres, negros, LGBTQ, ambientalistas), já que estes, exatamente, são envolvidos em suas formas domesticadas (FRASER, 2017, p. 61). O que ocorre é não outra coisa senáo a incorporação ou apropriação de demandas para que tudo permaneça como está. Uma vez que esse último ponto revela uma notável diferença com relação àquilo que Honneth irá defender, passemos a ele antes de comentar eventuais vantagens e desvantagens de Fraser.

Como visto, ao passo que Fraser toma como ponto de partida os discursos populares de crítica ao sistema, Honneth busca investigar suas normas constitutivas a fim de construir uma crítica interna às sociedades modernas - e não ao capitalismo. Aqui um esclarecimento prévio se faz necessário. Parece-me claro que o projeto de Honneth nem de longe se presta a reforçar filosoficamente a realidade já existente, como ele foi acusado de fazer. Em uma recente discussão com Jacques Rancière, ele operou uma distinção entre luta por reconhecimento interna e externa, segundo a qual a última, que possui um caráter revolucionário, não apenas é mais rara como também prescinde da análise sociológica dos desconfortos sociais e das motivaçôes imanentes para a crítica do presente (HONNETH, 2016, p. 106). Por isso, uma teoria do reconhecimento que se pretenda relevante para as lutas sociais deve manter-se ao rés do chão, preocupada com os movimentos sociais que explicita ou implicitamente propóem uma reinterpretação das normas de integração social vigentes, pois só assim ela poderá ser crítica do presente. Acontece, porém, que o próprio Honneth tem dificuldades em deixar claro o que são estes tais desconfortos. Em 
$O$ direito da liberdade ele fala de patologias sociais e de anomalias, ou falsos (HONNETH, 2011, p. 230); mas, posteriormente, em um artigo chamado "As enfermidades da sociedade" (HONNETH, 2015b), ele fala sobre uma concepção da sociedade como um organismo capaz de adoecer. Nesta última interpretação, que ele parece ter adotado desde então, não é claro qual o espaço para as dinâmicas de conflito internas às sociedades modernas. Ou seja, este é um projeto de "grande teoria", mas nem tanto de apropriação pelas lutas sociais.

A noção de uma teoria que remeta a desconfortos e dinâmicas internas, mas que não necessariamente se preste a uma apropriação política, fica clara na tentativa efetuada por Honneth de reconstruir a doutrina do socialismo como um ideal orientador da ação política, e não como um modelo formal de sociedade. De acordo com seu argumento, o que orienta os primeiros esforços dos socialistas é antes uma reformulação da ideia de liberdade individual nascida com a Revolução Francesa, a fim de livrá-la de tendências egoístas e individualistas e permitir sua dissolução nas práticas fraternais de consideração recíproca (HONNETH, 2015a, p. 47-48). (Honneth, 2015, p. 47-8). Tal definição, então, revela que o socialismo deve ser entendido como um impulso reflexivo que toma como objeto suas próprias condiçóes de realização, estas entendidas, por sua vez, como mais do que uma mera concepção melhorada de sociedade ou de uma fundamentação do dever ser; na medida em que se trata de um conceito orientado para o futuro, em seu uso sempre está implícita a intenção de "deixar a moderna sociedade tornar-se finalmente 'social' no sentido pleno da palavra, através da libertação ativadora de forças e potenciais que já a habitam" (HONNETH, 2015a, p. 86-87, grifos meus). Ou seja, não apenas uma ideia, o socialismo é tomado como uma referência normativa à ativação de forças já existentes.

Para Honneth, na era do industrialismo, três premissas acabaram por aprisionar a visão do socialismo em uma crosta que seria própria àquele período: a redução dos mercados ao capitalismo, a suposição da existência de uma força interna de resistência ao capitalismo e a hipótese da inevitabilidade da derrubada deste sistema engessaram de tal modo a doutrina socialista que ela perdeu de vista os avanços democráticos propiciados pela democracia liberal, fez uma aposta de trágicas consequências na revolução 
proletária e, principalmente, bloqueou a abertura a experimentos políticos, sociais e econômicos que ativassem de modo alternativo a ativação de forças e potenciais da modernidade. É exatamente a ativação deste último potencial de experimentação - aplicado particularmente às formaçóes político-econômicas dos mercados e da democracia liberal - que constitui a tarefa de uma doutrina socialista expurgada daquelas limitaçóes identificadas por ele (HONNETH, 2015a, p. 95). Todavia, na medida em que o ideal socialista trata de um projeto futuro de emancipaçáo social, é preciso que existam critérios de melhora na situação corrente e a justificativa para isso, dentro da arquitetura teórica que constrói, Honneth busca na obra de John Dewey.

De acordo com Honneth, na obra de Dewey, assim como na de Hegel, os conflitos sociais são interpretados como um elemento natural de qualquer forma de sociabilidade; mas, ao contrário da tradiçáo marxista, o motivo para que eles ocorram não é um fato histórico concreto (a apropriação privada dos meios de produção) cujos efeitos são fundamentalmente econômicos; antes, grupos sociais que se encontram em posição socialmente desvantajosa apelam a normas institucionalizadas que são aplicadas de modo a favorecer alguns outros grupos, e ao fazê-lo criticam grupos dominantes com base nas próprias normas sobre as quais estes se apoiam para hegemonizar uma determinada situação social (HONNETH, 2018b, p. 914). No entanto, é da constatação de que grupos sociais não permanecerão submetidos a situaçóes sociais nas quais experimentam desvantagens sociais que brota o entendimento de que há um comportamento crítico que se expressa como "prática cooperativa de interpretação" (HONNETH, 2018b, p. 916) e permite, em primeiro lugar, a desnaturalização de normas hegemonizadas por grupos dominantes; e, em segundo lugar, a demonstração de que normas mais inclusivas repousam na base da nova interpretação proposta (HONNETH, 2018b, p. 917-918). Esse conflito social através da reinterpretação somente pode aparecer como recorrente se as normas sociais forem entendidas como essencialmente abertas à interpretação (HONNETH, 2018b, p. 918), o que implica, no fim das contas, uma dupla abertura experimental: por um lado, as normas já existentes devem ser abertas à sua reinterpretação a partir daquelas forças e potenciais já existentes, propiciando uma dinâmica comunicativa aos conflitos sociais, 
uma vez que estes últimos são informados por normas e valores partilhados por todos os grupos envolvidos, a despeito de sua hegemonização por alguns; por outro lado, e na medida em que as interpretaçóes em disputa são experimentalmente construídas por meio da comunicação, elas assumem a forma prática de remoção permanente de bloqueios ao estabelecimento de novas e sempre mais amplas formas de comunicação (HONNETH, 2015a, p. 103-105). Dessa forma, Honneth enxerga uma permanente dinâmica de mudança - e, de fato, uma mudança crítica - nas articulaçóes internas às sociedades modernas, considerando que o conflito por reinterpretaçóes das normas e valores expressa um movimento de constante tentativa de institucionalizar certas visóes da sociedade até a emergência de novas interpretaçóes.

Quanto a isso, o projeto de Fraser resguarda uma ligação com as lutas sociais do presente, porque continua a tomar como seu ponto de apoio os paradigmas populares de justiça. Seu diálogo com as lutas anticapitalistas é muito mais explícito do que a crítica a padróes normativos realizada por Honneth. Por outro lado, o modelo de Fraser parece sofrer de um certo voluntarismo: a transnacionalização da crítica e a reformulação de paradigmas de justiça, por um lado, já são exercitadas por diversos movimentos sociais críticos à globalização há várias décadas. Mais ainda, caracterizar a emergência de discursos contra-hegemônicos como algo fundamentalmente positivo tende a desconsiderar aquilo que Honneth se esforça para mostrar: que as bases normativas da modernidade liberal são um projeto que vale a pena ser defendido. Aqui parece que, ao tratar dos movimentos contra-hegemônicos, talvez falte a Fraser uma ideia clara sobre o que os movimentos sociais do presente criticam quando pedem redistribuição, reconhecimento ou representação e isso se deve a um entendimento vago das dinâmicas internas dos próprios movimentos.

Trazendo para o atual contexto das lutas sociais no Brasil a ideia de que formas de reconhecimento estabelecido podem tanto servir de reforço a posiçóes de poder quanto sustentar discursos animosos, talvez seja possível afirmar - com muito cuidado, a fim de evitar a trivialidade (para usar um eufemismo) conservadora de afirmar que políticas identitárias geram ressentimento - que uma consequência inesperada da popularização política das demandas por reconhecimento foi a emergência de posiçóes opostas 
ao chamado empoderamento das minorias. Discursos antifeministas, contrários à igualdade homoafetiva se misturam hoje a discursos extremados e violentos contra quaisquer posiçóes consideradas progressistas e parecem ter alterado o panorama dos conflitos sociais e políticos no Brasil ${ }^{13}$. A particularidade de alguns desses discursos é que eles se constroem como defesa de posiçôes privilegiadas dentro da sociedade brasileira, chegando ao chocante extremo de que na pré-campanha presidencial de 2017/2018 no Brasil, um então candidato (competitivo) afirmasse que "as minorias têm que se curvar para as maiorias" 14 . É claro que não se quer afirmar que os movimentos supremacistas são lutas por reconhecimento; mas, em um contexto de globalização liberal, movimentos antiprogressistas radicalizados também deveriam ser vistos como movimentos contra-hegemônicos - como, aliás, Fraser parece perceber; para essa autora, o limite é que estes movimentos conservadores não seriam capazes de amalgamar o elemento do reconhecimento com sua retórica etnonacionalista. Dificilmente se pode considerar que, do ponto de vista de uma disputa política liberal, a centralidade desempenhada pela misoginia para a vitória de Donald Trump na eleição americana ou o recrudescimento da xenofobia na Europa do leste, na Holanda e na França, por exemplo, sejam variaçôes de expressões hegemônicas. Mais ainda, a transnacionalização da esfera pública pretendida por Fraser já está em curso, mas parece apontar para uma direção em que a superação da crise econômica se dá antes por meio do reforço de traços negativos das práticas de reconhecimento do que de uma articulação entre seu lado positivo e demandas por redistribuiçãao e representação, conforme o estudo de Kaletta (2008).

Assim, falta a Fraser explicitar de modo mais detalhado a dinâmica interna dos conflitos sociais que reflete na emergência de um modelo hiper-reacionário de neoliberalismo. Efetivamente, Honneth também acha que as críticas ao sistema são vagas e não apontam para uma direção clara ${ }^{15}$; mas, ao contrário de Fraser, ele parece saber muito bem o que a teoria deve criticar, ao passo que a ela falta uma definição do objeto da crítica. Colocado

13 Obviamente, considero que movimentos de direita e movimentos antiliberais são movimentos sociais.

14 A frase, entre outras, pode ser ouvida no seguinte link: https://www.youtube.com/watch?v=CAchAIPev2g.

15 Cf. a introdução a Honneth (2015a). 
de outro modo, para Honneth parece muito pouco estabelecer "o Capitalismo" como inimigo, enquanto para Fraser a questão parece revolver em torno deste conceito, que ela procura caracterizar de modo mais agudo. O problema, se pudesse ser colocado assim, está no fato de que ao ressaltar as dinâmicas sociológicas, Honneth chama atenção para um ponto importante: existem dinâmicas e tensóes próprias à definição mesma do que seja o capitalismo e de quais intençôes se associam a este sistema. Finalmente, este modelo de análise da dinâmica interna e das interpretaçóes normativas do sistema capitalista parece mais adequado a responder os dilemas característicos de um momento histórico marcado por uma crise política, de resto melhor caracterizada por Fraser do que por Honneth. Apenas que, em se tratando da construçáo de blocos que normalizam ou interpretam, como se queira, uma série de dinâmicas políticas, uma teoria sociológica das representaçóes normativas pode vir melhor a calhar do que uma teoria em que a resistência se sustenta em elementos do discurso político como transnacionalidade e contra-hegemonia. Nesse sentido, aquele outro modelo das representaçóes normativas me parece especialmente relevante ao se pensar na tradução deste debate à realidade social brasileira.

\section{Diálogos possíveis com a teoria sociológica brasileira}

E onde isso nos deixa, afinal? A possibilidade de apropriação das categorias analíticas "redistribuição" e "reconhecimento" por movimentos sociais foi um dos motivos que fomentaram o debate entre Fraser e Honneth. A proposta de Fraser de entender os movimentos críticos do capitalismo como contra-hegemônicos, porém, apresenta a fraqueza de caracterizar mal tanto o processo de globalização quanto as críticas ao atual estado das coisas. Além disso, frente ao recrudescimento de movimentos antiliberais, ignora aquilo que há de mais relevante no projeto de Honneth: a descrição da modernidade liberal como uma rede de entendimento mútuo entre sujeitos que democraticamente legitimam cada nova forma de organização social $^{16}$. Por outro lado, se a perspectiva adotada por Honneth, ao considerar a sociedade como um organismo e os desconfortos internos como

16 O valor do pensamento e da moralidade liberais para o projeto crítico me parece bem exposto em um artigo de Gabriel Cohn chamado "Razão e História", de 1995. 
patologias sociais não parece se prestar a qualquer apropriação coletiva por parte de atores em luta, tampouco sua teoria da permanente reinterpretação de normas se aproxima dos conflitos sociais concretos. Seu projeto se baseia, afinal, em uma reconstrução normativa das bases da modernidade democrática e, não por acaso, a defesa do potencial crítico desse projeto se deu por meio de um estudo no qual a ideia do socialismo é apresentada como uma formulaçáo da liberdade social. Assim, nenhum dos dois modelos parece dar conta da emergência de um paradigma antiliberal para o qual a articulação entre (ausência de) reconhecimento e (má)integração parece ser central. A intenção de Fraser de adicionar uma terceira dimensão à discussão, a da representação, em princípio parece positiva, já que pretende justamente ampliar o escopo das vozes que "contam" dentro de uma sociedade, mas este é justamente um aspecto que, no modelo de Honneth também recebe atenção, sendo apresentado como um processo de evolução moral. O problema é que, em momentos que os paradigmas de justiça são apropriados por movimentos que os distorcem, estas categorias parecem um tanto quanto voluntaristas. Se a questão, na verdade, for entender como diferentes movimentos sociais lidam com os problemas do reconhecimento e da redistribuição a fim de solucionar seus próprios problemas e não os da sociedade como um todo, então talvez seja preciso investigar como esses paradigmas de justiça são apropriados em meio aos conflitos sociais ou, colocado de outra forma, como se constituem ideias normativas em lugares específicos.

No clássico ensaio sobre "As ideias fora do lugar", Roberto Schwarz (2000[1977]) curiosamente se vale do vocabulário do reconhecimento para tratar da vida cultural brasileira no século XIX. Nesse ensaio e em outros correlatos, Schwarz procura expor as especificidades do capitalismo brasileiro a partir de sua relação com as leis e regras da ciência do capital, a economia política (SCHWARZ, 2000[1977], p. 11). Porém, ao invés de meramente ressaltar a particularidade do local, ele tenta demonstrar que, na relação do favor, o capitalismo assume uma forma, por um lado, específica ao relevo social do país; por outro lado, o faz justamente para corresponder à entrada do Brasil como nação autônoma na história contemporânea (SCHWARZ, 2009, p. 132). À combinação entre economia de matriz escravista e política de profissão liberal, Schwarz chama uma comédia 
ideológica, marcada pela impropriedade do pensamento; mas que, ao mesmo tempo, não se configura no nexo efetivo da vida ideológica nacional (SCHWARZ, 2000[1977], p. 15). Ora, é justamente a vida ideológica que constitui o tema central de seu ensaio, na medida em que, através dela, o autor pretende desnudar o favor como uma relação constitutiva da sociedade brasileira, sua "mediação quase universal" (SCHWARZ, 2000[1977], p. 16) - quase universal, aliás, porque devido à característica do uso economicamente racional da grande propriedade fundiária depender em grande medida da escravidão, a parte da população brasileira de então que a ela era forçada não fazia parte daquela vida ideológica. Resta, então, explicar como a relação do favor, sendo tão incompatível com o liberalismo quanto com a escravidão, marcou a forma da existência nacional.

Cabe notar, pois, que a explicação a ser dada a respeito da relação de favor visa a explicitar uma forma própria do liberalismo constituída no Brasil, já que sua existência é feita compatível com o favor: ao contrário do movimento europeu no qual se afirmou em oposição ao feudalismo, aqui ao liberalismo se adotou como ideal, enquanto na prática se manteve o arbítrio (SCHWARZ, 2000[1977], p. 17-18). E é aqui que o mais recente estudo de Honneth ganha significado. Ali, numa tentativa de tratar o conceito de reconhecimento em termos de história das ideias a partir de três diferentes tradiçóes de pensamento (francesa, inglesa e alemã), ele afirma que as diferentes versóes do conceito de maneira alguma se devem a disposiçóes espirituais ou mentalidades nacionais, mas antes à corresponsabilidade das condiçóes socioculturais sobre a maneira como pensadoras e pensadores de determinado local se associam a determinadas ideias ou a estas dão determinada coloração. Em seus próprios termos, o que Honneth tem diante dos olhos é a pergunta sobre se "[...] na tradição filosófica de um país qualquer certos motivos, temas e estilos de pensamento predominam justamente porque ali pressupostos institucionais e sociais estão dados que o diferenciam claramente de outro país" (HONNETH, 2018a, p. 17-18). O objeto de estudo de Honneth, ao tratar destas tradiçóes nacionais da história conceitual, não tem nenhuma relação com a história da formação da sociedade (tanto menos com a brasileira): ele se ocupa em demonstrar que na França a ideia de reconhecimento se orientou fundamentalmente pelo amor-prório conceitualizado por Rousseau, na 
Grã-Bretanha pelo autocontrole moral preconizado por Smith e na Alemanha pela autorrealização no sentido dado por Hegel. No entanto, entre outras Honneth se deixa guiar pela hipótese metodológica de que diferenças interpretativas no conceito de reconhecimento geraram diferentes efeitos tanto sobre aquelas e aqueles a quem se reconhecia quanto sobre quem reconhecia (HONNETH, 2018a, p. 188). Como conclusão deste artigo, gostaria de me apropriar desta hipótese para relacioná-la ao projeto de Schwarz em dois pontos: por um lado, no uso mesmo que este último faz da noção de reconhecimento; por outro, e talvez extrapolando as intenções de ambos os autores, quero caracterizar o empreendimento de Schwarz como uma teoria que diz respeito à reformulação normativa do liberalismo e, em consequência, da forma capitalista no Brasil, nos moldes em que Honneth mostra que conceitos normativos são rearranjados em relação a certos pressupostos institucionais e sociais. Com isso, irei defender a hipótese, que na verdade seria mais bem testada com um programa de pesquisa, de que, por um lado, há uma dinâmica específica das relações de reconhecimento no Brasil que, por outro lado, se deve ao nexo particular das relaçóes de reconhecimento e seus efeitos sobre os concernidos por aqui. Esta última hipótese, no frigir dos ovos, é o que permitirá defender que, mesmo direcionando seus modelos teóricos para análises sistêmicas, ainda há muitas possibilidades de diálogo com a teoria social brasileira nas obras de Fraser e Honneth.

Para começar, então, é melhor afastar a ideia de que Schwarz está em busca de uma interpretação de algo propriamente nacional. Em "Nacional por subtração", Schwarz parte da constatação de que, ao longo da história da cultura brasileira (e latino-americana), diversas interpretaçóes afirmam que a vida cultural do país tem sido experimentada como caráter inautêntico, postiço ou imitado e que esta inautenticidade expressa, por sua vez, o sentimento de contradição entre os países que servem de modelo ao Brasil e para nossa realidade nacional. Ao mesmo tempo, porém, em que este espelho ideológico "determina a direção do movimento", numa citação de Machado de Assis, a construçáo de problemas na esfera da cultura é repetidamente derrubada e reiniciada de outro ponto, rompendo assim a retomada de trabalhos predecessores. Em oposição a essa tendência, o afastamento do "influxo externo", seja em sua forma de direita ou de esquerda, busca 
revelar a descaracterização da cultura nacional e resgatá-la, mas esta operação era realizada como mera subtração (SCHWARZ, 2009, p. 114). Ocorre que a subordinação cultural é uma necessidade prática, realizada pela incorporação de ideias que permitem ao país participar autonomamente da ordem mundial (SCHWARZ, 2000, p. 28-29, 2009, p. 119). É por esse motivo que a crítica da cópia passa a valer apenas quando o país tem de lidar, agora independente, com sua própria posição na história contemporânea, isto é, a história do capitalismo: a cópia era aceitável e desejada em uma situaçáo colonial, na qual o letrado é tributário da metrópole; torna-se um problema, porém, quando se abre uma fresta nesse muro e o pastiche aparenta impedir o desenvolvimento nacional. A pergunta, então, está mal formulada.

Não se trata, afinal, de discutir a cópia, pois o sentido impróprio das ideias europeias no Brasil é, de acordo com Schwarz, um traço constante da reprodução social do país. Só que esse sentido impróprio não se deve à ausência de originalidade que acompanha o pastiche, e sim à imprecisão com que os mecanismos sociais aqui presentes recorrem ao sistema científico que pretendem reproduzir. Daí a comédia ideológica na combinação prática entre liberalismo e escravidão, mas daí também os efeitos que esta comédia gera sobre aqueles que a representam. Em um outro ensaio, chamado "Complexo, moderno, nacional e negativo", Schwarz procura demonstrar como as artimanhas narrativas do Machado de Assis de Memórias póstumas de Brás Cubas expóem, em sua forma dinâmicas centrais da realidade nacional. Em um registro "fora do esquadro" do romance realista tradicional, o narrador das Memórias alterna rapidamente entre diversos registros, aparentando uma volubilidade que, a respeito da personagem, destaca sua vontade de participar de várias dimensóes da vida burguesa, como a atividade produtiva (o emplastro), a política (o discurso sobre o comprimento do fardamento dos guardas) ou a reflexáo intelectual (a digressão após presenciar uma briga de cães), seguindo sua vaidade ao bel-prazer. No entanto, esse "feito de construção" narrativo revela, quanto ao relevo social brasileiro, que as etapas acima mencionadas são antes advindas do capricho individual do que da sistematização de um sentido da vida burguesa, como no romance realista europeu (SCHWARZ, 1989, p. 122). Nesse sentido, as etapas formativas ou expressóes individuais próprias da vida burguesa oferecem certa satisfação imediata, ainda que sem um sentido maior. 
Ao ser jogada nas circunstâncias brasileiras do final do século XIX, nas quais a camada organizadora da vida ideológica equilibra o pedido de reconhecimento dos países centrais e o desprezo por seus valores, a satisfação imediata ganha no romance o sentido de um "vaivém ideológico" ao qual a realidade brasileira e sua correspondente vida cultural estavam submetidas ao participar da história contemporânea (SCHWARZ, 1989, p. 124-125). Ao mesmo tempo, porém, que este vaivém ideológico é um traço de caráter da classe burguesa, a busca da satisfação imediata e geniosa é o que marca a postura do sujeito dessa classe. Não por acaso, o defunto Brás revela, já no além, que a criação do emplastro, vendida ao governo como nascida de intenção cristã e aos amigos revelada como cobiça - naturalmente aceitável - pelo lucro, fora também a eles dissimulada, pois que a intenção maior era a fama. Assim, o capricho de classe ganha seu correlato nos costumes individuais e "[...] a busca da vantagem econômica dá cobertura ao desejo de reconhecimento pessoal, e não vice-versa” (SCHWARZ, 1989, p. 117). Novamente nos deparamos com o vocabulário do reconhecimento e novamente o conceito é utilizado de modo muito parecido com a forma como o alemão o faz, ainda que mediado pela "coloração nacional" (HONNETH, 2018a, p. 16). Aqui, então, quero retomar a primeira parte de minha hipótese, a de que existiria uma dinâmica de reconhecimento própria às relaçôes sociais no Brasil.

N'“As idéias fora lugar”, Schwarz já introduzira o tema: a adoção das ideias e razóes liberais universalistas permitiam justificar objetivamente o momento de arbítrio que é um elemento natural da relação de favor, do que resulta uma "coexistência estabilizada" entre as formas e teorias do liberalismo burguês e de seu Estado e o clientelismo que os permeiam (SCHWARZ, 2000[1977], p. 18). No Brasil do final do século XIX, o liberalismo se torna um mecanismo de "compensação simbólica" do arbítrio, pois à prática personalizada do favor se adiciona o penhor do reconhecimento do prestígio individual, de modo que se cria uma relação na qual a favorecida e o favorecido (ou a reconhecida) justificam o favor recebido com argumentos racionais, dado que mediados pela ideologia do universalismo burguês. Nessa relação, em primeiro lugar, a compensação simbólica permite que todos reconheçam a intenção louvável que há no favor e também no agradecimento, tornando-a um ornato; mas, além disso, 
propicia o surgimento de uma cumplicidade permanente entre os envolvidos que contribui para o acochambramento do conflito social: "No momento da prestação e da contraprestação - particularmente no instantechave do reconhecimento recíproco - a nenhuma das partes interessa denunciar a outra, tendo embora a todo instante os elementos necessários para fazê-lo" (SCHWARZ, 2000[1977], p. 20). Todavia, nas "continuidades sociais" dessa mesma relação de cumplicidade, o caráter de classe da sociedade brasileira aparece com todo seu peso, já que, se o favor é dado àquelas e àqueles que são livres, também coloca a parte mais fraca da relação na posição de ter de celebrar a superioridade social de quem lhe favorece.

Essa dinâmica encontra eco em teses como a de Teresa Sales (1994), segundo a qual a cultura política resultante da sujeição dos homens livres e pobres ao poder dos senhores funciona como um cimento de relaçóes de mando e subserviência; de modo que mesmo o gozo de direitos de cidadania é mediado pelo favor ou pela participação daqueles membros da classe dominante que ocupam a posição de concessão de favores. Por isso, Sales chama essa dinâmica de "cidadania concedida". A dinâmica da tutela sobre os desfavorecidos ecoa ainda em trabalhos como o de Vera da Silva Telles, que afirma que o enfrentamento da pobreza nunca se deu no horizonte da cidadania, exatamente porque na lógica do Estado benevolente, sua existência deixa de ser compreendida como "problema que diz respeito aos parâmetros que regem as relaçôes sociais e às regras de reciprocidade" (TELLES, 2001, p. 20) 17. Em ambos os casos, que avançam teses próprias em interlocução com o ensaio inicial de Schwarz, as autoras - cada uma a seu modo - dão centralidade à dinâmica das relaçóes interpessoais e de reciprocidade e ao fato de que estas são marcadas por um processo formativo no qual as tais continuidades sociais devem ser compreendidas muito menos no sentido de invariáveis históricas do que como efeitos sobre a cultura política do país. Essa cultura política constituída a partir de uma versão nacionalmente colorida do liberalismo também gera relaçóes de reconhecimento específicas ao Brasil. Esta afirmação me parece condizente com a conclusão de Schwarz a respeito da dinâmica das relaçóes pessoais quando

17 Para um balanço da discussão sobre cidadania no Brasil informada pela relação entre reconhecimento $e$ redistribuição, ver: Silva, 2010. 
ele afirma que "[...] este reconhecimento é de uma conivência sem fundo, multiplicada, ainda, pela adoçáo do vocabulário burguês da igualdade, do mérito, do trabalho, da razão" (SCHWARZ, 2000[1977], p. 20).

Entretanto, se a dinâmica das relaçóes pessoais assume uma forma particular no Brasil, isso se deve - e esta é a segunda parte da minha hipótese - aos pressupostos institucionais e sociais de realização dessas relações, como dizia Honneth, de modo que mais do que diagnosticar a presença do favor e suas continuidades sociais, importa notar com Schwarz que o despropósito das ideias liberais no Brasil se deve antes ao fato de que "a ordem burguesa como um todo não se pauta pela norma burguesa” (SCHWARZ, 1989, p. 125), ou seja, ao deslocamento de um sistema ideológico que é também científico, mas que aqui revela a volubilidade das próprias normas dessa ciência. Portanto, quanto à segunda parte da hipótese, o que se deixaria dizer é que a forma da sociabilidade, a dinâmica mesma das relaçóes de reconhecimento recíproco (que estáo na base tanto do liberalismo europeu reconstruído por Honneth quanto da ordem brasileira do favor reconstruída por Schwarz) indica que aos nexos da vida cultural corresponde uma forma de reconhecimento e, afinal, um modelo, que se poderia chamar de normativo, do capitalismo no Brasil.

Quinze anos atrás, Fraser e Honneth estabeleceram um debate chamando atenção para suas implicaçôes políticas e a relaçóes dos termos discutidos com os movimentos sociais. Essa centralidade da análise dos movimentos sociais foi, aliás, muito presente no Brasil em diversos trabalhos. Desde entáo, como se viu, ambos se afastaram dos movimentos sociais e passaram a focar na caracterização do capitalismo, de modo que se poderia perguntar se este é um tema tão propício às ricas traduçóes e reapropriaçóes que se passaram com a questão dos movimentos sociais. A despeito dos respectivos movimentos de Fraser e Honneth em direção à análise da esfera econômica, a meu ver existem duas particularidades possíveis da apropriação deste debate no Brasil. A primeira, notada justamente através do trabalho de Schwarz (mas também indiretamente por Teresa Sales e Vera da Silva Telles), é que a ordem econômica no Brasil pode muito apropriadamente ser analisada como uma ordem na qual o conceito de reconhecimento continua central, sem necessariamente se limitar à dimensão das identidades culturais. A outra é que os conflitos 
sociais por reconhecimento continuam a desempenhar um papel relevante na organização da ordem capitalista brasileira. Aliás, algumas das mais ricas abordagens sobre o problema da relação entre redistribuição e reconhecimento no Brasil chamavam a atenção para o fato de que aqui a ausência das duas coisas não se misturavam como meros eixos de injustiça, e sim como potencializadores recíprocos (NEVES, 2007; SOUZA, 2003). Além disso, alguns trabalhos recentes (MACIEL, 2017; ROSENFIELD; MELLO; CORREAA, 2015; SOBOTTKA, 2015) têm apropriado a sociologia do reconhecimento como um instrumento de análise do trabalho e da integração social. Finalmente, também há uma apropriação de conceitos oriundos de Fraser e Honneth em tentativas de analisar a cidadania no Brasil (SILVA 2008, 2010, 2014), de modo que parece haver um grande espaço para articular a ideia de uma grande teoria, como Fraser e Honneth parecem fazer, com as interpretaçóes nacionais mais consequentes e sociologicamente informadas.

\section{Referências}

BROWN, W. Undoing the Demos. Neoliberalism's stealth revolution. New York: Zone Books, 2015 .

COHN, G. Razão e História. In: VIGEVANI, T. et al. (Org.). Liberalismo e Socialismo: Velhos Paradigmas. São Paulo: Editora UNESP, 1995. p. 23-36.

DURKHEIM, E. Liçóes de sociologia. São Paulo: WMF Martins Fontes, 2002.

ELIAS, N. O processo civilizador. Volume 1: Uma história dos costumes. Rio de Janeiro: Jorge Zahar, 1990.

ELIAS, N. O processo civilizador. Volume 2: Formação do Estado e civilização. Rio de Janeiro: Jorge Zahar, 1993.

FRASER, N. What's critical about Critical Theory? The case of Habermas and gender. New German Critique, n. 35, Special Issue on Jürgen Habermas, p. 97-131, spring/summer 1985.

FRASER, N. Rethinking recognition. New left review, v. 3, p. 107-120, may/june 2000.

FRASER, N. Recognition without ethics. Theory, culture \& society, v. 18, n. 2-3, p. 21-42, 2001.

FRASER, N. Social justice in the age of identity politics: Redistribution, recognition and participation. In: FRASER, N.; HONNETH, A. Redistribution or recognition? A politicalphilosophical exchange. London; New York: Verso: 2003a. p. 7-109. 
FRASER, N. Distorted beyond all recognition: a response to Axel Honneth. In: FRASER, N.; HONNETH, A. Redistribution or recognition? A political-philosophical exchange. London; New York: Verso: 2003b. p. 198-236.

FRASER, N. From redistribution to recognition Dilemmas of justice in a "postsocialist" age. In: OLSON, K. (Ed.). Adding insult to injury. Nancy Fraser debates her critics. London; New York: Verso, 2008a. p. 9-41.

FRASER, N. Reframing justice in a globalizing world. In: OLSON, K. (Ed.). Adding insult to injury. Nancy Fraser debates her critics. London; New York: Verso, 2008b. p. 273-291.

FRASER, N. Transnationalizing the public sphere: On the legitimacy and efficacy of public opinion in a Postwestphalian world. In: FRASER, N. Scales of justice. Reimagining political space in a globalizing world. New York: Columbia University press, 2009. p. 76-99

FRASER, N. Fortunes of feminism. From State-managed capitalism to neoliberal crisis. London; New York: Verso, 2013.

FRASER, N. From progressive neoliberalism to Trump - and beyond. American Affairs, v. 1, n. 4, p. 46-64, winter 2017.

FRASER, N.; HONNETH, A. Redistribution or recognition? A political-philosophical exchange. New York; London: Verso, 2003.

FRASER, N.; JAEGGI, R. Capitalism. A conversation. Cambridge; Madford: Polity, 2018.

FREYENHAGEN, F. Was ist orthodoxe Kritische Theorie?. Deutsche Zeitschrift für Philosophie, v. 67, issue 3, p. 456-469, jun. 2017.

HONNETH, A. Die soziale Dynamik von Mißachtung. Zur Ortbestimmung einer kritischen Gesellschaftstheorie. In: HONNETH, A. Das Andere der Gerechtigkeit. Aufsätze zur praktischen Philosophie. Frankfurt am Main: Suhrkamp, 2000. p. 88-109.

HONNETH, A. Redistribution as recognition: a response to Nancy Fraser. In: FRASER, N.; HONNETH, A. Redistribution or recognition? A political-philosophical exchange. London; New York: Verso: 2003a. p. 110-197. ?

HONNETH, A. The point of recognition: A rejoinder to the rejoinder. In: FRASER, N.; HONNETH, A. Redistribution or recognition? A political-philosophical exchange. London; New York: Verso: 2003b. p. 237-268

HONNETH, A. Luta por reconhecimento. A gramática moral dos conflitos sociais. Sáo Paulo: Editora 34, 2003c.

HONNETH, A. Trabalho e reconhecimento. Tentativa de uma redefinição. Civitas, v. 8, n. 1, p. 46-67, 2008. Disponível em: http://revistaseletronicas.pucrs.br/ojs/index.php/civitas/article/ view/4321. Acesso em: 10 out. 2018.

HONNETH, A. A textura da justiça: sobre os limites do procedimentalismo contemporâneo. Civitas, v. 14, n. 3, p. 345-368, 2009. 
HONNETH, A. Das Recht der Freiheit. Grundriß einer demokratischen Sittlichkeit. Berlin: Suhrkamp, 2011.

HONNETH, A. Barbarizações do conflito social: lutas por reconhecimento ao início do século XXI. Civitas, v. 14, n. 1, p. 154-176, 2014.

HONNETH, A. Die Idee des Sozialismus. Versuch einer Aktualisierung. Berlin: Suhrkamp, 2015a.

HONNETH, A. As enfermidades da sociedade. Aproximação a um conceito quase impossível. Civitas, v. 15, n. 4, p. 575-594, 2015b.

HONNETH, A. Remarks on the philosophical approach of Jacques Rancière. In: GENEL, K.; DERANTY, J.-P. (Ed.). Recognition or disagreement: a critical encounter on the politics of freedom, equality and identity. New York: Columbia University Press, 2016. p. 96-106.

HONNETH, A. Anerkennung. Eine europäische Ideengeschichte. Suhrkamp: Berlin, $2018 \mathrm{a}$.

HONNETH, A. Is there an emancipatory interest? An attempt to answer critical theory's most fundamental question. European Journal of Philosophy, v. 25, p. 908-920, 2018b.

KALETTA, B. Anerkennung oder Abwertung. Über die Verarbeitung sozialer Desintegration. Wiesbaden: VS Verlag für Sozialwissenschaften, 2008.

LUTA PELA REVOLUÇÃO. Bolsonaro diz que minorias devem desaparecer. 2017. 1 post. (57 min). Postado em 8 fev. 2017. Disponível em: https://www.youtube.com/watch?v=CAchA1Pev2g. Acesso em: 2 out. 2018.

MACIEL, F. Reconhecimento e desigualdade: da ética da autenticidade à cultura do novo capitalismo. Ciências sociais Unisinos, v. 53, n. 2, p. 281-291, 2017.

MATTOS, P. Desafios do reconhecimento nas relaçôes íntimas. Um debate com Axel Honneth.

Política \& Sociedade, Florianópolis, v. 17, n. 40, dez. 2018.

MCBRIDE, C. Recognition. Cambridge; Melden: Polity, 2013.

MELO, R. Reificação e reconhecimento. Um estudo a partir da teoria crítica da sociedade de Axel Honneth. Ethic@, v. 9, n. 2, p. 231-245, 2010.

NEVES, P. S. C. Luta anti-racista: entre reconhecimento e redistribuição. Revista Brasileira de Ciências Sociais, v. 20, n. 59, p. 81-96, out. 2005.

NEVES, P. S. C. Reconhecimento e desprezo social ou os dilemas da democracia no Brasil contemporâneo: algumas considerações à luz da questão racial. Política $\&$ sociedade, v. 6, n. 11 , p. 117-132, out. 2007.

PAIVA, A. R. Cidadana, reconhecimento e ação afirmativa no ensino superior. Civitas, v. 15, n. 4, p. 127-154, out./dez. 2015.

ROSENFIELD, C. L.; MELLO, L. G.; CORRÊA, A. S. Reconstrução normativa em Axel Honneth e os múltiplos justos no mercado de trabalho, Civitas, v. 15, n. 4, p. 664-685, 2015. 
SAAVEDRA, G.; SOBOTTKA, E. Discursos filosóficos do reconhecimento. Civitas, v. 9, n. 3, p. 386-401, set./dez. 2009.

SALES, T. Raízes da desigualdade na cultura política brasileiro. Revista brasileira de ciências sociais, v. 25, n. 9, 1994, p. 26-37.

SCHWARZ, R. Que horas são? São Paulo: Companhia das letras, 1989.

SCHWARZ, R. As ideias fora do lugar. In: SCHWARZ, R. Ao vencedor as batatas. Sáo Paulo: Duas cidades/Editora 34, 2000[1977].

SCHWARZ, R. Cultura e política. São Paulo: Paz e Terra, 2009.

SIEP, L. Mutual recognition: Hegel and beyond. In: IKKÄHEIMO, H.; LAITINEN, A. (Ed.). Recognition and social ontology. Leiden; Boston: Brill, 2011.

SILVA, J. P. Trabalho, cidadania e reconhecimento. São Paulo: Annablume, 2008.

SILVA, J. P. Nota crítica sobre a cidadania no Brasil. Idéias, n. 1, v. 1, p. 95-119, 2010.

SILVA, J. P. Por quê Renda Básica? São Paulo: Annablume, 2014.

SOBOTTKA, E. A. Reconhecimento. Novas abordagens em teoria crítica. São Paulo: Annablume, 2015 .

SOUZA, J. (Não) reconhecimento e subcidadania, ou o que é "ser gente"?. Lua Nova, n. 59, p. 51-73, 2003.

SOUZA, L. G. C. Do reconhecimento recíproco à sociedade efetivamente social. Civitas, vol. 17, n. 3, 2017, p. 98-114.

TELLES, V. S. Pobreza e cidadania. São Paulo: Editora 34, 2001.

\section{Redistribution or recognition, 15 years later. Considering the debate between Nancy Fraser and Axel Honneth, as well as its echoes in Brazil}

\section{Abstract}

The aim of this paper is to discuss how Nancy Fraser's and Axel Honneth's intellectual projects evolved through different paths after their 2003 debate and additionally if, and how, this paths could be proven fruitful to Brazilian social theory. I begin by showing how the debate was sparkled by the attempt of both Fraser and Honneth to offer a picture of present-day capitalism through the analysis of social struggle, particularly, through an understanding of how (I). After that, however, both of them focused on a rather systemic understanding of capitalism, which resulted in different conceptions of social conflict (II). Since, however, their fruitfulness for the 
understanding of social conflicts was very distinctive of the debate's reception in Brazil, the new path undergone by Fraser and Honneth also changes the way their models can be made useful here (III).

Keywords: Redistribution. Recognition. Social Conflicts. Capitalism. Reception in Brazil.

Recebido em 03/10/2018

Aprovado em 08/12/2018 